\title{
BINDING OF CORTICOSTEROIDS BY PLASMA PROTEINS. III. THE BINDING OF CORTICOSTEROID AND RELATED HORMONES BY HUMAN PLASMA AND PLASMA PROTEIN FRAC- TIONS AS MEASURED BY EQUILIBRIUM DIALYSIS ${ }^{1,2}$
}

\author{
BY WILLIAM H. DAUGHADAY WITH THE TECH NICAL ASSISTANCE OF IDA KOZAK
}

(From the Metabolism Division, Department of Medicine, Washington University School of Medicine, St. Louis, Mo.)

(Submitted for publication September 30, 1957; accepted December 5, 1957)

The physical state of the corticosteroid hormones in human plasma has been under investigation in this laboratory. Dialysis equilibrium experiments have been reported which show that the 17-hydroxycorticosteroids of plasma are bound to plasma proteins to an extent of more than 90 per cent (2). Of the plasma protein fractions tested for their cortisol binding power with high concentrations of cortisol, albumin had the greatest binding affinity. The importance of albumin was apparently further supported by equilibrium paper electrophoresis conducted with cortisol-4-C $\mathrm{C}^{14}$ in which the greatest concentration of radioactivity was associated with the albumin component of plasma (3). It was difficult, however, to explain the greater binding of 17-hydroxycorticosteroids in plasma than that which occurred in equilibrium dialysis experiments using cortisol and albumin. This discrepancy has prompted a thorough reinvestigation of corticosteroid binding at physiologic levels of hormone by plasma and plasma protein fractions. Progress has been greatly aided by the availability of labeled steroids, greatly simplifying the analytical techniques. Evidence indicating the presence of two independent corticosteroid binding systems in plasma is presented in this paper.

\section{METHODS}

Heparinized blood was obtained from normal adult laboratory workers and students in midmorning following a light breakfast. In most experiments plasma was used for binding studies on the day that it was

1 Reported in part at the Annual Meeting of the Central Society for Clinical Research, November, 1956 (1).

2 This investigation was supported by a research grant, C-255, from the National Institute of Arthritis and Metabolic Diseases of the National Institutes of Health, Public Health Service. drawn, although little loss of binding affinity occurred after storage at $-10^{\circ} \mathrm{C}$. The conditions of dialysis were the same as previously reported (2). Usually $10 \mathrm{ml}$. of plasma in a cellophane bag (Visking nojax, 18/32 casing) was dialyzed against $40 \mathrm{ml}$. of Krebs phosphosaline buffer, $\mathrm{pH} 7.4$ (4), in a large test tube. Where a high degree of binding was anticipated, $80 \mathrm{ml}$. of buffer was used. In several experiments where the amount of plasma or plasma protein fraction was limited, $5 \mathrm{ml}$. of protein solution was dialyzed against $40 \mathrm{ml}$. of buffer. The radioactive and nonradioactive steroids were included in the dialysis buffer by diluting an alcoholic solution of the steroids with buffer. The final alcohol concentration of alcohol was below 1 per cent in all experiments. Although equilibrium conditions are reached for all practical purposes in 24 hours, the dialyses were allowed to continue for 48 hours at $4^{\circ} \mathrm{C}$.

The buffer was separated from the plasma at the conclusion of the dialysis and the volume measured. It was then extracted three times with ethyl acetate using 1.0, 1.0 , and 0.5 volumes of solvent. The extracts were pooled and evaporated to dryness in a boiling flask. The protein concentration of the plasma was measured by a biuret method (5). The plasma was extracted a single time with five volumes of chloroform in a stoppered tube. Emulsions were broken by centrifugation and the supernatant plasma was removed by suction. Anhydrous sodium sulfate was used to dry the extract and an aliquot, usually $20 \mathrm{ml}$., was evaporated to dryness in a small boiling flask.

The steroid residues were carefully dissolved in 1.5 $\mathrm{ml}$. of ethyl alcohol and then $0.5 \mathrm{ml}$. of 8 per cent glucose was added and mixed well. Duplicate aliquots of this solution were pipetted into tared brass cups containing disks of lens paper. The cups were reweighed after drying under an infrared light. Radioactivity was determined with a windowless gas flow counter operating in the proportional range. The observed counts were corrected to infinite thinness using an experimentally determined curve prepared with cortisol-4-C $\mathrm{C}^{14}$. The glucose provides a smooth adhesive glaze. Recovery of added cortisol-4- $\mathrm{C}^{14}$, using these extraction and counting techniques, has varied between 90 and 105 per cent. Control experiments in the absence of plasma have failed to show significant adsorption of the labeled steroids on the glass or dialyzing membranes. 


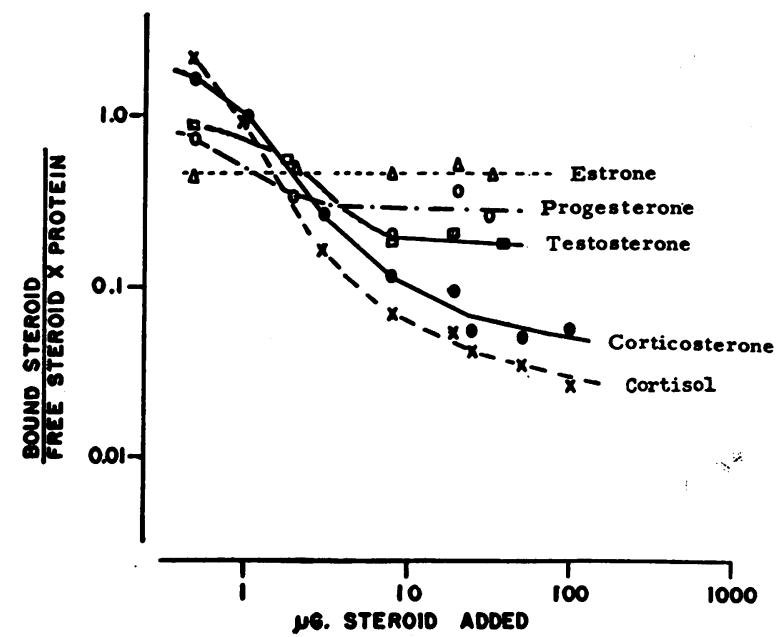

Fig. 1. Changes in the Binding Affinity of Normal Human Plasma for Cortisol-4-C ${ }^{14}$, Corticosterone-4-C ${ }^{14}$, Progesterone-4-C ${ }^{14}$, Testosterone-4-C ${ }^{14}$, AND Estrone-16-C IN The Presence of Increasing Amounts of Total Steroid in a Standard Dialysis Equilibrium System Containing 10 ml. of Plasma AND 80 ML. OF BUFFER

Corticosterone-4- $\mathrm{C}^{\mathbf{1 4}}$ and cortisol-4- $\mathrm{C}^{14}$, with specific activities of 1.467 millicuries per millimole, were obtained from the Endocrinology Study Section of the National Institutes of Health. Progesterone-4-C ${ }^{14}$, with a specific activity of 1.63 millicuries per millimole, was prepared by Tracerlab, Boston, Massachusetts. Estrone16- $\mathrm{C}^{\mathbf{4}}$ and estradiol-16- $\mathrm{C}^{14}$, with specific activities of 0.74 millicuries per millimole, were supplied by Charles $\mathrm{E}$. Frost Co., Montreal. Testosterone-4-C $\mathrm{C}^{\mathbf{1 4}}$, with a specific activity of 1.44 millicuries per millimole, was obtained from the Ray Chem Laboratories, Elmsford, New York.

The nonradioactive steroids were either in crystalline form or as a fine crystalline suspension in talc (U. S. P. Reference Standard Steroids). The steroids were extracted from the latter preparations with ethyl alcohol and diluted to the desired concentration with the dialysis buffer.

The combining affinity of a protein solution for a given steroid under the specified conditions of protein and steroid concentration has been expressed in the following way :

$\mathrm{C}$ (combining affinity) $=\frac{\text { Bound steroid }}{\text { Unbound steroid } X \text { protein }}$

Unbound steroid: This is the steroid which is not bound to protein as determined by the steroid concentration of the buffer corrected for the lower water content within the dialysis bag.

Bound steroid: The steroid bound to protein is the difference between the concentration of total steroid within the dialysis bag and the concentration of free steroid.

Protein: The concentration of protein within the bag after dialysis is expressed as milligrams per milliliter.
This expression has the form of an association constant but cannot be calculated in molecular terms because the molecular weights of the binding proteins other than albumin are unknown. For most of the steroids studied $\mathrm{C}$ is not constant for human plasma but is greatly influenced by the concentrations of the steroids in the system. This simple formulation provides an empiric method for comparing the binding observed with plasma and plasma protein fractions of different protein and steroid concentrations.

\section{RESULTS}

The binding of progesterone-4-C $\mathrm{C}^{14}$, corticosterone-4-C $\mathrm{C}^{14}$, cortisol-4-C ${ }^{14}$, testosterone-4-C $\mathrm{C}^{14}$, and estrone-16- $\mathrm{C}^{14}$ by human plasma has been measured in the presence of different amounts of carrier steroid added to the dialysis equilibrium system. The changes in combining affinities with increasing concentrations of steroid have been plotted on a double logarithmic scale in Figure 1. At the lowest concentrations studied, the two corticosteroid hormones (cortisol and corticosterone) are bound nearly completely to the plasma proteins. When more steroid is added to the system there is a large decrease in the affinity of binding. After a transition phase, further additions of cortisol and corticosterone make relatively little difference in the measured affinity. The behavior of estrone in comparable experiments is quite different in that the binding affinity is not significantly influenced by the amount of estrone added to the system. The results with progesterone

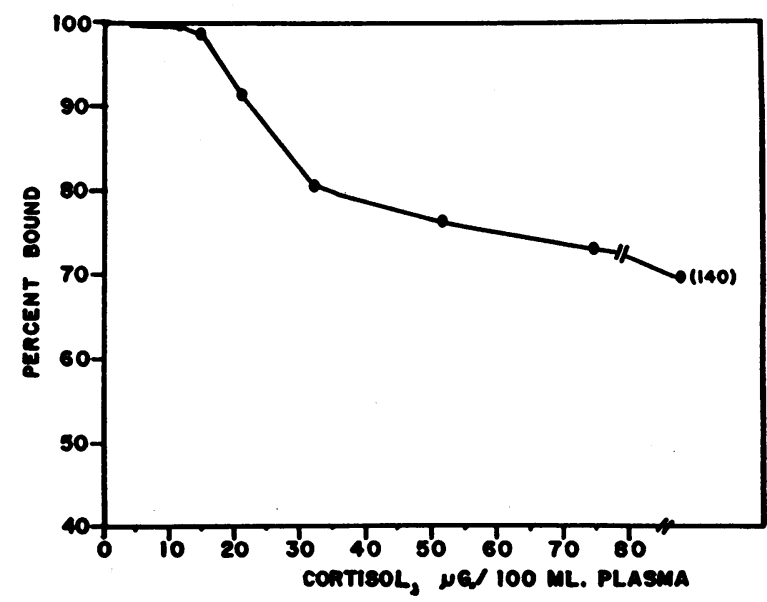

Fig. 2. The Calculated Changes in the Percentage of Cortisol Binding by Human Plasma Plotted Against the Total Cortisol Concentration of Plasma

These calculations were made from the data summarized in Figure 1. 
BINDING OF CORTICOSTEROID HORMONES BY PLASMA

TABLE I

A comparison of the ability of related steroids to inhibit the binding of cortisol-4-C14*

\begin{tabular}{|c|c|c|c|c|c|c|}
\hline \multirow[b]{2}{*}{ Competing steroid } & \multirow[b]{2}{*}{ Amount } & \multirow[b]{2}{*}{ Plasma } & \multicolumn{2}{|c|}{ F-4-C14t } & \multirow[b]{2}{*}{ Protein } & \multirow[b]{2}{*}{$C \ddagger$} \\
\hline & & & Free & Bound & & \\
\hline \multirow{3}{*}{ None } & \multirow{3}{*}{$\begin{array}{l}\mu g . \\
0\end{array}$} & & $c p m / m b$ & $c p m / m l$. & $m g . / m l$. & \\
\hline & & $\begin{array}{l}\text { A } \\
\text { B }\end{array}$ & $\begin{array}{l}4.1 \\
3.3\end{array}$ & $\begin{array}{l}297 \\
262\end{array}$ & $\begin{array}{l}66.1 \\
60.7\end{array}$ & $\begin{array}{l}1.095 \\
1.33\end{array}$ \\
\hline & & $\mathrm{D}$ & 3.7 & 245 & 61.5 & 1.08 \\
\hline \multirow[t]{2}{*}{$9 \alpha$-fluorocortisol } & \multirow{2}{*}{$\begin{array}{l}10 \\
10.2\end{array}$} & $\mathbf{B}$ & 5.9 & 254 & 63.7 & 0.68 \\
\hline & & $\mathrm{D}$ & 4.7 & 252 & 62.8 & 0.86 \\
\hline \multirow{3}{*}{$\begin{array}{l}\text { d, 1-aldosterone } \\
3 \alpha, 11 \beta, 17 \alpha, 21 \text {-tetrahydroxy- } \\
\text { pregnane-20-one } \\
11 \beta, 17 \alpha, 21 \text {-trihydroxy- } \\
\text { pregnane-3, 20-dione }\end{array}$} & \multirow{2}{*}{$\begin{array}{l}10 \\
10\end{array}$} & $\mathrm{C}$ & 5.8 & 225 & 60.3 & 0.64 \\
\hline & & A & 7.2 & 248 & 67.1 & 0.51 \\
\hline & 10 & A & 9.3 & 237 & 68.8 & 0.37 \\
\hline Progesterone & 8.7 & D & 12.4 & 208 & 61.3 & 0.27 \\
\hline Cortisone & 10 & B & 15.9 & 205 & 59.9 & 0.22 \\
\hline $11 \alpha$-hydroxycortisol & 10 & B & 15.2 & 222 & 61.2 & 0.24 \\
\hline 11-desoxycorticosterone & 10 & A & 25 & 179 & 71.1 & 0.10 \\
\hline $17 \alpha$-hydroxyprogesterone & 9.14 & $\mathrm{C}$ & 25.5 & 138.5 & 61.7 & 0.080 \\
\hline Prednisolone & 9.97 & $\mathrm{C}$ & 29.5 & 125.7 & 60.8 & 0.070 \\
\hline 11-desoxycortisol (Compound S) & 10 & $\mathbf{B}$ & 36.9 & 121.1 & 60.6 & 0.054 \\
\hline 21-desoxycortisol & 9.57 & $\mathbf{C}$ & 29.1 & 97.8 & 61.4 & 0.055 \\
\hline Corticosterone & 10 & A & 32 & 113 & 66 & 0.053 \\
\hline 2-methylcortisol & 10.4 & $\mathrm{D}$ & 32 & 106 & 64 & 0.053 \\
\hline Cortisol & 10 & A & 34.4 & 110.6 & 69 & 0.048 \\
\hline & 10 & B & 38.5 & 106.5 & 63 & 0.044 \\
\hline & 10 & $\mathrm{C}$ & 32.3 & 92.3 & 64 & 0.045 \\
\hline & 10 & $\mathrm{D}$ & 31.5 & 98.0 & 61.4 & 0.051 \\
\hline
\end{tabular}

*Conditions-Ten ml. of plasma dialyzed 48 hours against $40 \mathrm{ml}$. of Krebs phosphosaline buffer with $0.5 \mu \mathrm{g}$. of cortisol-4-C 14 plus indicated amounts of competing steroid. The table is a compilation of studies on four separate plasmas which are identified for direct comparisons.

$\dagger$ F-4-C ${ }^{14}=$ Cortisol-4-C $\mathrm{C}^{14}$.

$\ddagger \mathrm{C}=$ Combining affinity.

and testosterone are intermediate between those obtained with estrone and the corticosteroid hormones. Minor difference between the curves cannot be considered significant because the experiments were conducted with different samples of normal human plasma.

The data on cortisol binding have been recalculated and presented in a form which is more easily interpreted physiologically (Figure 2 ). In the graph, the percentage of the total plasma cortisol bound to plasma proteins has been plotted against the total plasma cortisol concentration. Certain assumptions were made for these calculations. The initial concentration of cortisol of this plasma was assumed to be identical with the measured concentration of 17 -hydroxycorticosteroids $(7.5 \mu \mathrm{g}$. per $100 \mathrm{ml}$.). The degree to which water entered the dialysis bag was assumed to be 5 per cent of the original volume. ${ }^{3}$ These data

\footnotetext{
${ }^{3}$ Recently, the entrance of buffer into $10 \mathrm{ml}$. of plasma has been found to average 12 per cent of the original volume. Recalculation of the data with this figure leads to no significant alteration in Figure 2.
}

permitted a calculation of the specific activity in the system. From this calculation the concentration of cortisol in the plasma at the end of the dialysis was found.

The binding curve for cortisol shows that virtually all the cortisol is protein bound when the total cortisol concentration is below $15 \mu \mathrm{g}$. per $100 \mathrm{ml}$. of plasma. The percentage of bound steroid decreases rapidly between 15 and $30 \mu \mathrm{g}$. per $100 \mathrm{ml}$. of plasma, and more slowly thereafter.

The abrupt decrease in affinity of plasma for cortisol and corticosterone with addition of carrier steroid, as illustrated in Figure 1, has permitted a study of the specificity of the binding site for cortisol. The ability of a number of structurally related steroids to inhibit the binding of cortisol-4- $\mathrm{C}^{14}$ has been examined. In the experiments summarized in Table I the degree of binding of $0.5 \mu \mathrm{g}$. of cortisol-4-C $\mathrm{C}^{14}$ by plasma has been determined alone or in the presence of the indicated amounts of the steroids listed. The results are tabulated in an array with the steroids which block the binding of cortisol-4- $\mathrm{C}^{14}$ to the 
TABLE II

$A$ comparison of the ability of related steroids to inhibit the binding of corticosterone-4-C $C^{14 *}$

\begin{tabular}{|c|c|c|c|c|c|c|}
\hline \multirow[b]{2}{*}{ Competing steroid } & \multirow[b]{2}{*}{ Amount } & \multirow[b]{2}{*}{ Plasma } & \multicolumn{2}{|c|}{ B-4-C14 $\dagger$} & \multirow[b]{2}{*}{ Protein } & \multirow[b]{2}{*}{$\mathrm{C} \ddagger$} \\
\hline & & & Free & Bound & & \\
\hline \multirow{3}{*}{ None } & \multirow[t]{3}{*}{ Mg. } & \multirow{3}{*}{$\begin{array}{l}\text { A } \\
\text { C }\end{array}$} & $c p m / m l$. & $c p m / m l$. & \multicolumn{2}{|l|}{$m g . / m b$. } \\
\hline & & & 1.0 & 311 & \multirow[t]{2}{*}{64} & \multirow{2}{*}{$\begin{array}{l}4.86 \\
2.11\end{array}$} \\
\hline & & & 1.8 & 249 & & \\
\hline d, l-aldosterone & \multirow{3}{*}{$\begin{array}{l}10 \\
8.02 \\
9.5\end{array}$} & \multirow{3}{*}{$\begin{array}{l}\text { B } \\
\text { C } \\
\text { A }\end{array}$} & 2.8 & 221 & \multirow{3}{*}{$\begin{array}{l}60 \\
65 \\
65\end{array}$} & \multirow{3}{*}{$\begin{array}{l}2.11 \\
1.33 \\
1.14 \\
0.85\end{array}$} \\
\hline Androsterone & & & 1.8 & 249 & & \\
\hline $\begin{array}{l}\text { 11-dehydrocorticosterone } \\
\text { (Compound A) }\end{array}$ & & & 5.4 & 297 & & \\
\hline Progesterone & \multirow{6}{*}{$\begin{array}{l}8.7 \\
9.14 \\
9.5 \\
10 \\
9.57\end{array}$} & \multirow{6}{*}{$\begin{array}{l}\text { B } \\
\text { A } \\
\text { A } \\
\text { A } \\
\text { A } \\
\text { B }\end{array}$} & 7.8 & 226 & \multirow{6}{*}{$\begin{array}{l}60 \\
66 \\
65 \\
65 \\
63 \\
60\end{array}$} & \multirow{6}{*}{$\begin{array}{l}0.48 \\
0.21 \\
0.12 \\
0.095 \\
0.086 \\
0.104\end{array}$} \\
\hline 11-desoxycorticosterone & & & 17 & 244 & & \\
\hline 11-desoxycortisol (Compound S) & & & 24 & 197 & & \\
\hline Cortisol & & & 28 & 171 & & \\
\hline Corticosterone & & & 30 & 165 & & \\
\hline & & & 21 & 132 & & \\
\hline
\end{tabular}

*Conditions-Ten ml. of plasma dialyzed 48 hours against $40 \mathrm{ml}$. of Krebs phosphosaline buffer containing $0.5 \mu \mathrm{g}$. of corticosterone-4-C $\mathrm{C}^{14}$ plus indicated amounts of competing steroid. The table is a compilation of measurements on three separate plasmas which are identified for direct comparison.

$\dagger$ B-4-C ${ }^{14}=$ Corticosterone-4-C ${ }^{14}$.

¥ $\mathrm{C}=$ Combining affinity.

greatest extent at the bottom and those which block the binding of cortisol the least at the top.

Table I provides considerable information concerning the specificity of the binding site of plasma which has the highest affinity for cortisol. The increased ability of 11-desoxycorticosterone and 17-hydroxycorticosterone to displace cortisol-4$\mathrm{C}^{14}$, as compared to progesterone, indicates that the hydroxyl group at either the 17 or 21 carbon positions increases the ability of a corticosteroid to displace cortisol. The possession of a second hydroxyl group at position 11,17 , or 21 by a corticosteroid possessing one such group further increases the affinity of the compound for the cor- tisol binding site. For example, less cortisol-4-C $\mathrm{C}^{14}$ is bound in the presence of corticosterone than with desoxycorticosterone; less cortisol-4-C ${ }^{14}$ binding occurs in the presence of compound $\mathrm{S}$ as compared to 17-hydroxyprogesterone. It is noteworthy that a steroid possessing hydroxyl groups at all three positions (postions 11, 17, and 21), namely cortisol, only decreases the binding of cortisol-4-C ${ }^{14}$ slightly more than a corticosteroid with only two such hydroxyl groups. In these experiments the magnitudes of the effects induced by the three positions of hydroxylation were similar.

Further evidence for the comparative specificity

TABLE III

Binding of cortisol-4-C $C^{14}$ by plasma protein fractions*

\begin{tabular}{|c|c|c|c|c|c|}
\hline Protein & Source & Protein & Free F & Bound F & $\mathrm{C}+$ \\
\hline $\begin{array}{l}\text { II }_{1,2,8} \\
\text { III } \\
\text { IV-1 } \\
\text { IV-4 } \\
\text { V } \\
\text { IV (No. 347)\| } \\
\text { IV-1 (No. 17437)\| } \\
\text { Normal human plasma }\end{array}$ & $\begin{array}{l}\text { Protein Fndn. } \\
\text { Protein Fndn. } \\
\text { Protein Fndn. } \\
\text { Protein Fndn. } \\
\text { Protein Fndn. } \\
\text { Cutter Labs. } \\
\text { Cutter Labs. }\end{array}$ & $\begin{array}{c}m g . / m l . \\
32 \\
(44) \ddagger \\
22 \\
27 \\
27 \\
40 \\
28 \\
\text { (mean of } 7 \text { ) }\end{array}$ & $\begin{array}{c}c p m / m l . \\
54 \\
54 \\
49 \\
15 \\
31 \\
6 \\
6\end{array}$ & $\begin{array}{c}c p m / m b . \\
8 \\
19 \\
60 \\
708 \\
84 \\
206 \\
226\end{array}$ & $\begin{array}{l}0.005 \\
0.008 \\
0.055 \\
1.7 \\
0.10 \\
0.87 \\
1.26 \\
2.08\end{array}$ \\
\hline
\end{tabular}

*Conditions-Four per cent protein solutions were prepared from lyophilized preparations in Krebs phosphosaline buffer. Denatured proteins were removed by centrifugation. Ten $\mathrm{ml}$. of solution was dialyzed against $40 \mathrm{ml}$. of $\mathrm{Krebs}$ phosphosaline buffer containing $0.5 \mu \mathrm{g}$. of cortisol-4-C $\mathrm{C}^{14}$.

$\dagger \mathrm{C}=$ Combining affinity.

$\$$ The protein determination of this fraction is questionable because of the turbidity of the solution which developed with the Lowry method (13).

$\$$ Only $3 \mathrm{ml}$. of protein solution was available for dialysis. This was dialyzed against $40 \mathrm{ml}$. of $\mathrm{Krebs}$ phosphosaline buffer.

|| Eighty ml. of Krebs phosphosaline buffer was used for these experiments. 
of cortisol binding is the unexpected finding that the configuration of the 11-hydroxyl group exerts a major influence. Substitution of the $11 \alpha$-hydroxyl for the natural $11 \beta$-hydroxyl of cortisol led to a marked decrease in the ability of the unnatural compound to displace cortisol-4-C ${ }^{14}$ from binding by plasma. The 11-keto group likewise decreased competition.

Certain other structural changes decrease the affinity of a steroid for the cortisol binding site when evaluated in this way. These changes include the introduction of the 18-aldehydic group (compare cortisol binding in the presence of aldosterone as compared to corticosterone), the $9 \alpha$-fluoro group, and the reduction of the $\Delta^{4}$-3ketone. Some structural modifications caused little change in the ability of the steroid to displace cortisol. The unsaturation at the 1 to 2 position of prednisolone and the introduction of the 2-methyl group in 2-methyl-cortisol decreased the competing power only slightly.

A more limited study of the specificity of the binding site for corticosterone-4- $\mathrm{C}^{14}$ has been conducted using the same method as employed in the experiments presented in Table I. The ability of related steroids to depress corticosterone-4- $\mathrm{C}^{14}$ binding appears to follow the same general principles described for cortisol (Table II).

The corticosteroid binding properties of lyophilized plasma protein fractions have been reexamined under the conditions used for whole plasma (Table III). The high degree of binding present in normal human plasma cannot be attributed to albumin (Fraction V). Of the fractions examined, the highest binding affinity for cortisol has been found in Fraction IV-4. A considerable difference was found in the binding exhibited by this fraction when prepared by different laboratories. Some activity was found in samples of Fraction IV and IV-1. Samples of Fraction VI have not yet been available for study.

Recently a preparation of Fraction IV-4 (Protein Foundation run No. 1033) has been studied which has a higher corticosteroid binding power than the sample described in Table III. The binding affinity of this preparation for a number of active steroid hormones has been compared with a sample of Fraction V. The contrast between the binding specificities of these two protein fractions has been presented graphically

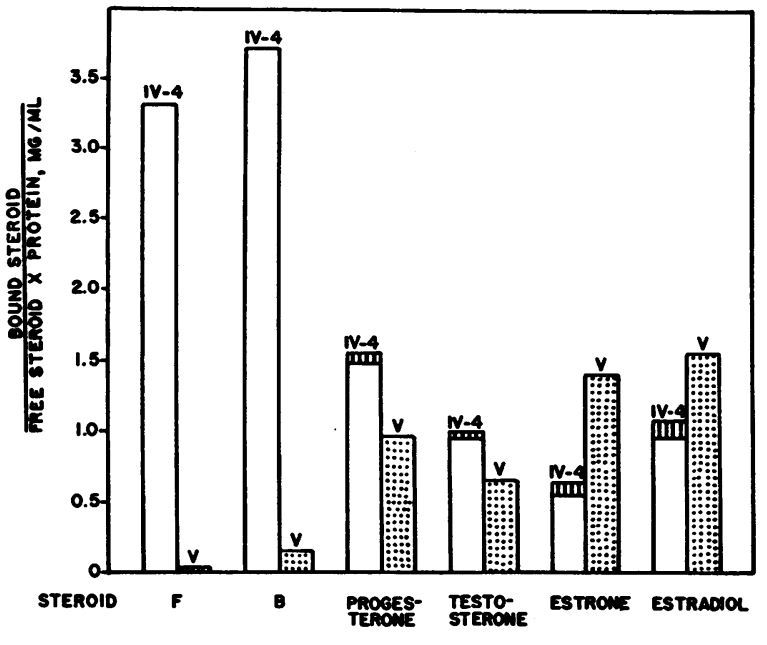

Fig. 3. A Comparison of the Binding of Cortisol4- $\mathrm{C}^{14}$ (F), Corticosterone-4-C $\mathrm{C}^{14}$ (B), Progesterone4- ${ }^{14}$, Testosterone-4-C ${ }^{44}$, Estrone-16-C ${ }^{14}$, AND Estradiol-16-C ${ }^{14}$ by Human Plasma Protein Fractions V AND IV -4

The dialysis equilibrium system consisted of $5 \mathrm{ml}$. of solution containing $3.2 \pm 0.2$ per cent protein in buffer and $40 \mathrm{ml}$. of buffer containing $0.25 \mu \mathrm{g}$. of the indicated labeled steroid.

(Figure 3). Fraction IV-4 has the greatest affinity for the corticosteroid hormones (cortisol and corticosterone), and much less affinity for testosterone, estrone, and estradiol. The binding of progesterone is intermediate between these two extremes. As the sample of Fraction IV-4 probably contains as much as 15 per cent albumin, ${ }^{4}$ a rough calculation can be made of the degree to which this contamination contributes to the observed affinity by using the formula for combining affinity previously described. The correction has been indicated at the top of the columns pertaining to Fraction IV-4. In the case of the two estrogens this is a significant fraction of the total binding affinity but this fraction is unmeasurable with cortisol and corticosterone. In contrast to Fraction IV-4, Fraction V has the greatest affinity for the estrogenic hormones and the least affinity for cortisol and corticosterone.

\section{DISCUSSION •}

In an earlier publication from this laboratory, it was concluded that the degree of binding of 17-

4 This information was provided by Dr. R. Pennell of the Blood Characterization and Preservation Laboratory of the Protein Foundation, Boston, Mass. 
hydroxycorticosteroids in plasma of patients receiving cortisone or adrenocorticotropic hormone exceeded that which could be explained by albumin binding (2). The analytic difficulties inherent in the chemical determination of 17 -hydroxycorticosteroids have been circumvented by the use of hormones labeled with $\mathrm{C}^{14}$. The results of the experiments reported in this paper clearly indicate that there are at least two corticosteroid binding systems in human plasma.

The binding agent in the first system may be called corticosteroid binding globulin. With small amounts of cortisol added to plasma, the high degree of binding which occurs can be attributed almost entirely to this protein. It would appear significant that there is considerable specificity of the binding site for the physiologically active corticosteroids produced by the adrenal cortex. Alterations in the steroid molecule, often of a minor nature, usually decreased the ability of a steroid to inhibit the binding of cortisol-4- $\mathrm{C}^{14}$. There did not seem to be any relation between the biological activity of synthetically prepared steroids and their affinity for the cortisol-4- $\mathrm{C}^{14}$ binding site. The amount of the corticosteroid binding globulin in plasma must be very small because the binding capacity seems to be saturated at steroid concentrations between 15 and $30 \mu \mathrm{g}$. per $100 \mathrm{ml}$. of plasma.

Albumin is a second corticosteroid binding protein of human plasma. The ability of albumin to bind a great number of steroids including cortisol has been abundantly established $(2,6-8)$. The factors determining the affinity with which albumin binds steroids differ from those which were observed with human plasma in the present experiments. Eik-Nes, Schellman, Lumry, and Samuels (6) have shown that the strength of binding by albumin was for most steroids inversely related to the number of polar groups and the degree of water solubility. Westphal (7) has observed a spectral shift in the ultraviolet absorption associated with the $\Delta^{4}$-3-ketone after binding of the steroid by albumin indicating that this group probably participates in the binding. The presence of the 11-hydroxyl group weakened this interaction markedly. Hydroxyl groups at the 17 and 21 positions were without much influence (8). It is difficult to exceed the binding capacity of albumin because of the large amounts present in plasma.

The corticosteroid binding which occurred with different plasma protein fractions provides additional evidence favoring the dual nature of corticosteroid binding. The binding affinity of Fraction IV-4 for cortisol and corticosterone was much greater than that of albumin. Considerable loss of activity must have occurred during fractionation because the affinity of the most active fractions was hardly greater than that of fresh whole plasma. It would be premature to associate the corticosteroid binding activity with any particular subfraction until a higher recovery of total plasma activity is achieved. An electrophoretic separation of corticosteroid binding globulin and albumin will be described separately (9).

Recently, Sandberg and Slaunwhite (10) have published a comprehensive study of steroid binding using both ultrafiltration and dialysis equilibrium methods. They also find the greatest binding of cortisol with Fractions IV-4 and V. The results of these workers differ, however, in not indicating the predominant binding of corticosteroids by Fraction IV-4 which we have observed (Figure 3). Indeed, the binding of most of the steroid hormones examined by Sandberg and Slaunwhite was almost as great as cortisol with the exception of cortisone, which was bound significantly less. This latter finding agrees well with the limited ability of cortisone to displace cortisol from the high affinity binding site of plasma, shown in Table I. Minor differences in the experimental conditions can explain the more evident predominance of corticosteroid binding in the present paper. We have used approximately one-fifth of the amount of steroid per milligram of Fraction IV-4 employed by Sandberg and Slaunwhite. This small difference in steroid concentration can be expected to reduce the degree of binding of cortisol relative to the other steroid hormones.

With the present incomplete fractionation of plasma proteins it is impossible to state that the corticosteroid binding globulin, as defined in this paper, is a single protein distinct from other steroid binding globulins in plasma. It may be that one protein has a binding site of high affinity for corticosteroid hormones at one locus and binds a number of other hormones at other loci. The 
reversible type of binding which occurs in dialysis equilibrium experiments differs from the firm binding of estrogens to protein when an incubation is carried out with liver slices in the presence of plasma as reported by Szego and Roberts (11). The significance of this latter type of binding has recently been challenged (10).

The physiologic significance of plasma proteins which bind hormones is far from clear. A similarity between the corticosteroid binding globulin and the thyroxine binding globulin (12) is suggested by these studies despite the much tighter binding of thyroxine. Binding an active hormone to a protein hardly seems an efficient way to "transport" the hormone across the capillary membrane to the cells on which hormonal action is exerted. Robbins and Rall (12) have suggested that the physiologically significant thyroxine of the plasma may be the minute concentration of unbound thyroxine rather than the proportionally much greater concentration of protein bound thyroxine. The same may be said about cortisol in that the effect exerted on the tissues may be proportional to the concentration of freely diffusible hormone. The determination of plasma 17-hydroxycorticosteroids would be, therefore, only an indirect index of the concentration of the physiologically significant unbound steroid.

\section{SUM MARY}

1. The binding of cortisol-4-C $\mathrm{C}^{14}$, corticosterone4-C ${ }^{14}$, progesterone-4- $\mathrm{C}^{14}$, testosterone-4- $\mathrm{C}^{14}$, and estrone-16- $\mathrm{C}^{14}$ by human plasma has been compared in dialysis equilibrium experiments. Whereas the binding of estrone is influenced relatively little by the amount of steroid in the dialysis system, the affinity of plasma for cortisol and corticosterone is greatly affected by the amount of steroid added. With additions of less than $1 \mu \mathrm{g}$. per $10 \mathrm{ml}$. of plasma, about 99 per cent of cortisol in plasma is protein bound. The affinity of plasma decreases abruptly with further additions of steroid. The behavior of testosterone and progesterone was intermediate between that of the corticosteroid and estrogenic hormones.

2. The ability of related corticosteroids to displace cortisol-4- $\mathrm{C}^{14}$ and corticosterone-4- $\mathrm{C}^{14}$ from the binding sites of high affinity in plasma has been examined. The presence of at least two hydroxyl groups at the $11 \beta, 17 \alpha$, or 21 positions, and an intact $\Delta^{4}$-3-ketone in ring $\mathrm{A}$ are required for maximum displacement of the radioactive hormone. Competition is greatly decreased by the presence of the 11 -keto, the $11 \alpha$-hydroxyl, the 18 -aldehydic or the $9 \alpha$-fluoro groups on a corticosteroid molecule.

3. Dialysis equilibrium experiments with plasma protein fractions using low concentrations of cortisol-4-C ${ }^{14}$ demonstrated that Fraction IV-4 had the highest affinity for cortisol and corticosterone. The ability of albumin to bind these hormones under these conditions was markedly less. Fraction IV-4 had less affinity for progesterone, testosterone, estrone and estradiol than for the two corticosteroid hormones.

4. It is suggested that the high binding affinity of plasma for corticosteroid hormones in low concentrations is due to the presence of a small amount of a binding protein of high binding affinity. The binding capacity of this protein is exceeded when the concentration of cortisol rises substantially above the normal concentration. The binding of cortisol by plasma at high concentrations of hormone can be attributed largely to albumin.

\section{ACKNOWLEDGMENTS}

Plasma protein fractions used in these experiments were supplied by Dr. R. Pennell, Protein Foundation, Boston, Mass.; Dr. J. H. Hink, Cutter Laboratories, Berkeley, Calif.; and Dr. T. D. Gerlough, E: R. Squibb and Sons, New Brunswick, N. J. The steroids were generously donated by the following organizations: Ciba; Merck Sharp and Dohme Laboratories; Schering Research Division; and the Upjohn Company.

\section{REFERENCES}

1. Daughaday, W. H. Evidence for two corticosteroid binding systems in human plasma. J. Lab. clin. Med. 1956, 48, 799.

2. Daughaday, W. H. Binding of corticosteroids by plasma proteins. I. Dialysis equilibrium and renal clearance studies. J. clin. Invest. 1956, 35, 1428.

3. Daughaday, W. H. Binding of corticosteroids by plasma proteins. II. Paper electrophoresis and equilibrium paper electrophoresis. J. clin. Invest. 1956, 35, 1434.

4. Krebs, H. A., and Eggleston, L. V. The oxidation of pyruvate in pigeon breast muscle. Biochem. J. 1940, 34, 442.

5. Weichselbaum, T. E. An accurate and rapid method for the determination of proteins in small amounts 
of blood serum and plasma. Amer. J. clin. Path. 1946, 16, technical section p. 40.

6. Eik-Nes, K., Schellman, J. A., Lumry, R., and Samuels, L. T. The binding of steroids to protein. I. Solubility determinations. J. biol. Chem. 1954, 206, 411.

7. Westphal, U. Steroid protein interactions. III. Spectrophotometric demonstration of interaction between proteins and progesterone, desoxycorticosterone and cortisol. Arch. Biochem. 1957, 66, 71.

8. Westphal, U., and Ashley, B. D. Spectrophotometric observations on interaction between proteins and $\Delta^{4}$-3-ketosteroids. Fed. Proc. 1957, 16, 269.

9. Daughaday, W. H. Binding of corticosteroids by plasma proteins. IV. The electrophoretic demonstration of corticosteroid binding globulin. J. clin. Invest. 1958, 37, 519 .
10. Sandberg, A. A., and Slaunwhite, W. R. The binding of steroids and steroid conjugates to human plasma proteins in Recent Progr. Hormone Res., G. Pincus, Ed. New York, Academic Press Inc., 1957, vol. 13, p. 209.

11. Szego, C. M., and Roberts, S. Hepatic intervention in the binding of estrogen to rat serum albumin in vitro. J. biol. Chem. 1956, 221, 619.

12. Robbins, J., and Rall, J. E. The interaction of thyroid hormones and protein in biological fluids in Recent Progr. Hormone Res., G. Pincus, Ed. New York, Academic Press Inc., 1957, vol. 13, p. 161.

13. Lowry, O. H., Rosebrough, N. J., Farr, A. L., and Randall, R. J. Protein measurement with the Folin phenol reagent. J. biol. Chem. 1951, 193, 265.

\section{ANNOUNCEMENTS OF MEETINGS}

The Fiftieth Annual Meeting of THE AMERICAN SOCIETY FOR CLINICAL INVESTIGATION will be held in Atlantic City, N. J., on Monday, May 5, 1958, at 9:00 A.M. at the Casino Theater on the Steel Pier.

The Fifteenth Annual Meeting of THE AMERICAN FEDERATION FOR CLINICAL RESEARCH will be held in Atlantic City, N. J., at the Casino Theater on the Steel Pier on Sunday, May 4, 1958, at 9:00 A.M.

THE ASSOCIATION OF AMERICAN PHYSICIANS will hold their Seventy-First Annual Meeting in Atlantic City, N. J., at the Casino Theater on the Steel Pier on Tuesday, May 6, 1958, at 9:30 A.M. and in the Vernon Room, Chalfonte-Haddon Hall on Wednesday, May 7, 1958, at 9:30 A.M. 